This item was submitted to Loughborough's Research Repository by the author.

Items in Figshare are protected by copyright, with all rights reserved, unless otherwise indicated.

\title{
Lean manufacturing in public services: prospects for value creation
}

PLEASE CITE THE PUBLISHED VERSION

http://dx.doi.org/10.1007/978-3-642-14319-9_4

VERSION

AM (Accepted Manuscript)

LICENCE

CC BY-NC-ND 4.0

\section{REPOSITORY RECORD}

Jaaron, Ayham A.M., and C.J. Backhouse. 2019. "Lean Manufacturing in Public Services: Prospects for Value Creation”. figshare. https://hdl.handle.net/2134/10746. 
This item was submitted to Loughborough's Institutional Repository (https://dspace.lboro.ac.uk/) by the author and is made available under the following Creative Commons Licence conditions.

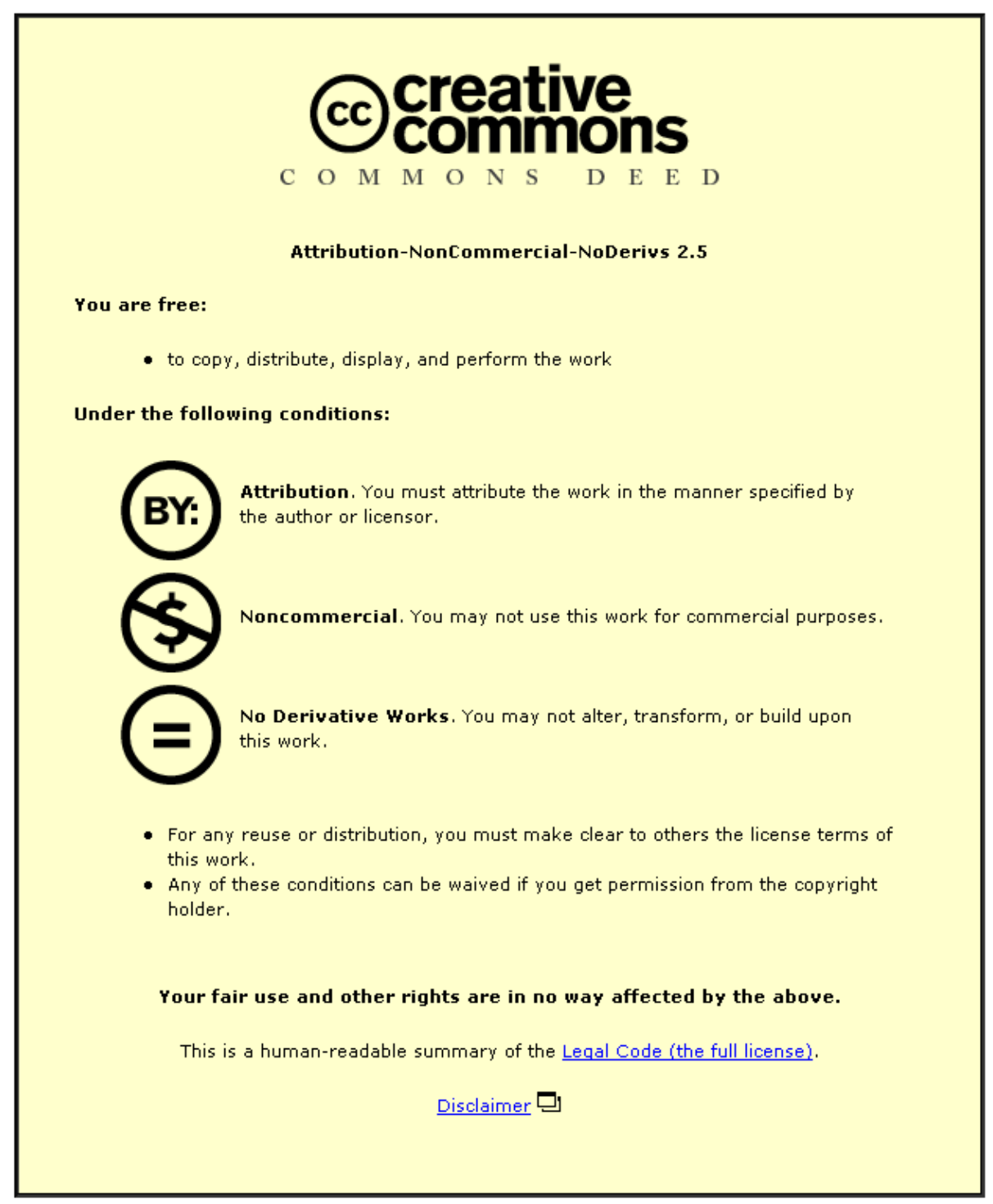

For the full text of this licence, please go to: http://creativecommons.org/licenses/by-nc-nd/2.5/ 


\title{
Lean Manufacturing in Public Services: Prospects for Value Creation
}

\author{
Ayham Jaaron and Chris Backhouse \\ Wolfson School of Mechanical and Manufacturing Engineering, Loughborough \\ University, Leicestershire, LE11 3TU, UK, \\ \{A.A.M.Jaaron, C.J.Backhouse\}@lboro.ac.uk, \\ http://www.lboro.ac.uk
}

\begin{abstract}
The purpose of this paper is to investigate the utilization of lean manufacturing systems in public service operations for potential added value. A case study of lean manufacturing implementation at a UK city council was carried out using in-depth interviews with key personnel coupled with documents collection. The Organizational Commitment Questionnaire (OCQ) was administered among front-line employees. Results show that lean manufacturing systems could create significant added value to the business and employees. A strong relationship was demonstrated between the lean manufacturing implementation and the affective commitment level of employees. This paper is one of a few studies that demonstrate the applicability of manufacturing systems in other settings and that they can generate significant added value for the service department and its employees.
\end{abstract}

Key words: Public services, Lean manufacturing, Affective commitment, Service delivery

\section{Introduction}

Managers in many organizations are often constrained to ineffective courses of action in call centre projects which fail to achieve a satisfactory level of service quality [1]. In many occasions, the ineffective call centres project implementation and management is a result of the inappropriate use of Key Performance Indicators (KPIs). This is due to the excessive focus on statistics to satisfy targets [2]. This causes the system to hide many repetitive tasks and procedures that are considered as waste. The waste present in the service system makes the service process sluggish and time consuming which in turns harms the customer service level and dissipates monetary resources. Furthermore, studies on call centre management practices and environment have revealed that there is a tendency to focus on efficiency (volume of calls handled) rather than effectiveness (service quality and customer orientation) [3]. In other words there is a focus on quantity rather than quality [4] [5]. This focus on quantity explains such issues as inflexibility, sluggish response procedures, stifling of employees human qualities, and increased stress on employees [6]. 
However, service departments have to achieve targets if the parent organization is to maintain their support [2]. Due to the current economical pressures, public services must include a demonstration for Value For Money (VFM) for the operations and services they run. This is a challenge for managers with the need that substantial cashable efficiency savings will be required, ideally without impacting upon service performance. This resulted in a quest for ways to achieve savings through the application of transformational reviews of systems and managerial regimes.

Nowadays, lean manufacturing systems are widely used in many manufacturing industries around the globe, they have also witnessed acceptance from service industries [7] as a possible strategy to face increasing customer expectations and intensive economical pressures for reduced costs. Several studies have emerged in this regard to investigate the lean manufacturing approach use in service departments. For instance, Levitt [8] argued that service departments could achieve significant benefits from adopting the principles of lean manufacturing. Similarly, Bowen and Youngdahl [9] made the case, on the basis of Levitt [8] work, that service departments must continue their endeavour to adopt manufacturing production models. They argued that the lean manufacturing approach to services has reduced non-value added from service processes while acheiving customer focus. However, these studies, like many others, have failed to link this adoption of lean manufacturing with the effects on employees affective commitment and their role in creating a high quality service.

This paper aims to explain the gradual shift in management thinking in public sector service departments towards adopting manufacturing models as a substitute for traditional functional specialization. It investigates the impact of the lean manufacturing systems on the added value to the public services departments in terms of employees' affective commitment leveraging. In the following sections, the concepts of lean manufacturing are presented, the concept of affective commitment and both its prerequisites and significance on service quality are then discussed. This is followed by a description of the case study organization and data collection procedures. Finally, results are presented and conclusions discussed.

\section{Lean Manufacturing and Service Operations}

Lean manufacturing principles were introduced for the first time in Toyota Production System (TPS) as a comprehensive strategy for the elimination of waste from work operations [10]. The elimination of waste is achieved through the creation of value stream mapping of operations that deliver solutions and products in minimal time [11] [12]. Arguably, Sugimori et al. [13] was the first to discuss the TPS in the academia [14], they have introduced the two basic concepts that Toyota has recognised as the guiding principles for its new methodology. The first was the attaining of low cost production through waste elimination. The second is the utilisation of their workers capabilities to the utmost by treating them as human beings. In Sugimori et al.'s [13] own words: It (i.e. Toyota) has 
built up a system of respect for human. This respect was due to the companys belief that respecting human abilities and capabilities is where the competitive success lies. Workers were allowed to make decisions they found necessary for the work, such as stopping the line when a problem happens, make work changes, and make any improvement initiative to remove any waste found in the system. Lean manufacturing is also defined as the ability of the organization to do more work with less resources [11], thus reducing overall costs. It embraces a number of strategies that comprise the whole leanness philosophy, these are JIT (whereby products and parts are only produced when a customer demand is received), workers empowerment, zero inventory, team working, continuous improvement, value streams and quick system set-ups [15].

However, a gap seems to be present in service organizations between the management focus and that of front-line. While the premium interest of management in service organizations, similar to other types of organizations, is the cost, the one used at the customer interface level is of service quality and customer satisfaction [12]. To cover this gap of interest the management has to understand that as the service level increases the operating costs decrease. If the customer receives what he wants from the organization from the first contact created, then the customer is receiving a quality service with least-cost incurred by the organization, since the customer does not need to call again to get what he wants.

Service departments are typically exposed to a greater demand variety from the customer than are manufacturing departments [16]. In order for the service organization to absorb demand variety it needs an adaptive mechanism similar to that of a living organism that can adapt to the surrounding environment in order to function and thrive. Such an organic structure is typified by devolved decision making processes [17]. The characteristics of this approach are that jobs are wide in scope and employees are allowed to act on a variety of tasks, to learn and to build relationships with customers [18]. These tasks are not governed by rigid rules and procedures; the team shares the responsibility of the work. Hierarchy of control is not usually present thus allowing the team to identify the right person to solve a particular problem. Help desks, for example, are typically mechanistic structure units by the managerial systems they use. However they are outwardfacing entities exposed to the ever-changing environment. The emphasis that mechanistic structures must be shielded from the environment strongly indicates that help desks must be given an organic face [6].

\section{Affective Commitment Significance}

Organizational commitment has emerged as a platform for the identification of the relationship between organizations and their individuals [19]. Mathieu and Zajac [20] have found that the concept of organizational commitment has taken two dimensions in empirical studies, some have described it as a consequence when linking it with work environment, role states and organizational structures, others have described it as an antecedent when linking it with turnover, 
absenteeism and personal behaviour. In the review of literature, organizational commitment has been defined as the employee's psychological attachment to the organization [21] [22]. Allen and Meyer [23] argued that organizational commitment has three different components. First, affective commitment where the person strongly identifies with the goals of the organization and desires to remain a part of it because he wants to do so. Second, continuance commitment where the employee commits to an organization because of the high cost associated with leaving the organization. Third, normative commitment where the employee attaches himself to and remains a part of an organization that has invested resources in training or educating him.

Several studies have demonstrated that organizational commitment, job satisfaction and quality of service are interrelated [24] [25]. Affective commitment was found to be more effective than the other two components in influencing the service quality of customer-contact employees. The impact of affective commitment on service quality can be explained by understanding its antecedents [26] [27]. The antecedents encompass that if the organization provided the chance for its employees to fulfil their personal ambitions; desire of achievement, autonomy, and a sense of control on what the employees have, then employees are more likely to develop affective commitment with their employer. Affective commitment is also related to the employer ability to decentralize decisions making processes to be at the employees level, this gives employees a feeling of personal importance and value in the organization. Employees whose working experiences are rewarding and fulfill their own aspirations are more likely to develop affective commitment, and are ready to exert more effort on behalf of the organization to deliver high levels of service quality than those whose working experiences were less rewarding [28]. However, managerial practices and organizational structures conventionally implemented in call centres across the service industry can inhibit the development of a rewarding job experience for employees. This is due to standardised work procedures, monitored dialogue [29] [30], mechanisation of customer-employee contact and an emphasis on quantity statistics and targets over the quality of interaction [5] [31]. As a result employees possess reduced levels of affective commitment in such environment.

Ellis and Taylor [30] found that despite strident calls for new forms of organizational structures and management styles, managerial practices and organizational structures commonly implemented in call centres inhibit the development of a rewarding job experience for employees. The consequence is high employee turnover, low service quality and ultimately low customer satisfaction. However, it is argued in this paper that the concepts of lean manufacturing of respecting human capabilities and abilities, discussed earlier, play a major role in leveraging affective commitment of front-line employees. lean manufacturing this way provides employees with a sense of control on what they have, and gives them a feeling of personal importance and value in the organization. Due to these reasons employees working under the lean manufacturing principles are more likely to develop affective commitment with their organization [26]. 
In fact, affective commitment has a direct impact on organisational efforts for financial savings. This is due to the direct and indirect cost of employees turnover if they lack a sufficient level of affective commitment. Direct costs (i.e. quantifiable) include advertising and recruiting cost, interviewing cost, orientation or training cost, and employment application processing cost. While indirect costs (i.e. unquantifiable) include reduced quality assurance, increased sick time and decreased morale that is perceived as of invaluable effect on call centre environment and customer retention [32]. Furthermore, a highly affectively committed employee does exceptional job of delivering a quality service that retains customers [22] [28]. The longer the customer stays with the company, the more the profits gained would be. Customers who stay with the company for longer become accustomed to use the service more and thus profits increase [33].

\section{Case Study}

An independent case study was carried out in the Information and Communication Technologies (ICT) department of Stockport Council in England. The ICT Department has a help desk that supports more than 6000 customers across the council departments and related directorates for their hardware and software needs and IT problem solving. The help desk has a total of 18 employees working on phones and emails. There were two team leaders in the ICT help desk responsible for day to day operations of the work. In general, the work of the employees is very similar to call centre environment where customers call seeking information on how to solve IT problems or for technical support. The purpose of the help desk from customer perspective was to provide customer with IT support and systems he needs and will need to do his job effectively. In contrast, the purpose of the original system (before transformation) from employees perspective-derived from the management practices- is to do my task and meet the set targets. This mismatch of perceived purpose was identified as resulting in a sub-optimum solution.

It was recognized that Stockport Councils aspirations for moving from excellent to exceptional require a continuation in the improvement of both performance and the use of resources. Further, the governments expectations include local authorities identifying 3\% cash releasing efficiency gains each year and demonstrating and embedding VFM in a more explicit manner. Therefore, it was likely that some form of step change will be necessary to meet in full the challenges that lie ahead. In response to the need for improvement initiatives the ICT department was a part of a strategic approach to achieving the improvements and efficiencies necessary to enable the council to demonstrate VFM in the delivery of its priority outcomes, through the transformation of business and service delivery processes and methods. The transformation programme followed lean manufacturing principles and covered all functions of the ICT department. The transformation programme progressed in three stages:

Stage 1: (Check) This stage started with demand analysis. A check team was recruited to perform this crucial stage of the programme. The check team 
collated information about what customers expect and want from the ICT help desk and what matters to them most. Data collated in this process enabled identification of the major demands coming into the area. A visual representation of each operation carried out in the help desk was developed as a flow chart. Identification of waste (actions not adding any value from the customers point of view) was then carried out. All processes classified as waste were marked in red on the process flow chart, and processes that add value from the customer point of view were marked in green.

Stage 2: (Redesign) The team redesigned the processes flow taking what have been learned in the check phase considering the customer wants and then mapping out the service of the future. The new design focused on minimizing non-value adding activities from a customer point of view. However, it was recognized that complete elimination of non-value adding activities from a customer point of view was never going to be possible. The new processes were tested, redesigned and re-tested again to make sure that customers get the best possible service before going live in the help desk.

Stage 3: (Roll-In) This stage covered implementation of the new model within the ICT help desk by a gradual rolling in of employees. As the check team progressed and the discussion was held about the roll-in of staff to this new way of working, it was key to continue the identification of appropriate training. To ensure sustainability of the new system design a comprehensive staff training needs were identified as they arose in the help desk.

The data was primarily collected through in-depth interviews and questionnaires conducted within the premises of Stockport Council, followed by documents gathering. 16 interviews in total were conducted in research site, 11 were front-line employees from the help desk, three middle managers from the ICT department and two senior managers one is holding the services director position and the other is the head of transformation. Thematic analysis [34] methods were employed to identify the main themes constituting the interviewee replies. This process consisted of a set of steps that allowed the generation of central themes. First, the research objectives along with the interview transcripts of this study were revised in order to identify general theoretical topics that could help generate a coding framework for the interview transcripts. A coding framework is a set of words or topics that are carefully selected to represent a general meaning of what has been said in the interviews segments [35]. Second, the interview transcripts were carefully revised again with the aim of dividing the text into meaningful parts to reduce the data. Every part was then given a code that belongs to a pre-defined criteria (i.e. specific word or topic). Third, after a signing a code for each text in the interviews, another revision was carried out to find codes with common themes. This way allowed for clustering text segments around specific themes that was used later for interpretations.

The 15-items Organizational Commitment Questionnaire (OCQ) was introduced by Porter et al. [36] to measure affective commitment, this was further shortened to a nine-items version. The shortened nine-items version was found to be more superior than the full 15-items version and more effective for measuring 
affective commitment [19]. Hence, the nine-items OCQ was administered in this study. It used an interval five options likert-type scale with the following anchors (strongly disagree, disagree, undecided, agree, and strongly agree). Documents were also collected through the head of transformation and services director. These comprised mainly reports about the nature of the project, progressed achieved and the project management plans.

\section{Case Study Findings}

The in-depth interviews conducted were focused on exploring employees working conditions under the new system and the impact that lean manufacturing has on service operations and managerial roles, the thematic analysis of the interviews generated the following central themes:

Theme 1- working experience: Employees indicated that they now enjoy wider scope of demand and authority to make decisions on phones. The team share responsibility of the work and informal channels of communication is encouraged to allow for a quicker transfer of knowledge between members. Employees now get correct information from customers that could deliver a better service without the need for repeating phone calls. Customers get what they want with the elimination of transfer from pillar to post. One employee is now dealing with the demand in a very efficient way with more time to speak to customer. Employees indicated that $85 \%$ of incoming phone calls are now dealt one stop. The management focus shifted from targets and statistics towards percentage of one stop calls and demand analysis. No phone calls recording was required and no pre-specified call durations were used. In addition, no scripts were used for employees to follow when talking to customers.

Theme 2- performance measurement: Employees are measured and evaluated on the basis of sticking to working principles of meeting customer demand. Team leaders log into the system to track each employee profile on daily basis to see the frequency of phone calls that have been met one stop, each employee is expected to handle at least 5 calls every day and complete them one stop. Employees commented that it is now possible to complete phone calls one stop due to the authority they have to make decisions and deliver the optimal solution required. In addition, The correct information collected from customers allowed for the precise identification of problems and thus a satisfactory solution to be provided.

Theme 3- departmental Integration value: Interviewees recognised communication between departments as important. However, they indicated that the functional specialization model created a silo between sections and departments as every department was viewed as a separate entity that should not interfere with the work of other departments, one manager stated we thought functional specialization was an efficient way to do the work but it was not...the system was frustrating and did not allow for open doors policy. Interviewees claimed that they have witnessed huge improvements in communication, formal 
and informal meetings at managers and departmental level. As a result, frontline employees were provided with quick feedback and support channels from other business units when needed to serve customers.

Theme 4- operational value: All managers regarded the following contributions as important tools to prove lean manufacturing principles value in public service departments: cutting down the waste in the service system that makes the service process sluggish and time consuming. Saving resources/money without cut in service. $85 \%$ of calls are done one stop by one employee for each call. lean manufacturing principles is the only model that works with the Human side to change the nature of work. Reduction in repeated calls and thus improved productivity and handling capacity. Systems clarity and transparency due to continuous demand analysis. Focus on customer services rather than maintaining the system.

Measuring Affective Commitment: The data collected from the nineitem OCQ questionnaire was analysed to examine how affectively committed the help desk employees were. Responses were sought from statements such as I talk up this council to my friends as a great organizations to work for and this council really inspires the best in me in the way of job performance. A total of 18 employees working at the help desk were available at the time of the questionnaire, all employees responded targeting a 100\% response rate. Responses to the nine-items are averaged to obtain a single score for each item; the standard deviation for each item was also calculated see Table 1. An overall mean for the nine items of 3.77 was achieved. This provided a clear indication of fairly high affective commitment level among employees in the Help Desk, where a return of 3.0 would indicate a neutral level of affective commitment and where values of 3.5 are typical in many organisations. A summary of the results is shown in Fig 1.

\section{Analysis and Discussion}

The traditional help desk environment represents the latest form of Taylorist principle as it is a common trend in help desks globally to practice high levels of monitoring over their employees [37]. However, the results of interviews conducted with front-line employees at the help desk have shown that the implementation of lean manufacturing principles has delivered numerous improvements. Employees under the new system are no longer restricted to repetitive job handling procedures or target achieving dilemma, they are empowered to do the job in the best way they see is vital to satisfy customer needs. Hence, employees have opportunities to develop their working skills by handling a wide range of challenging demands on daily basis. Their performance is evaluated on their ability to help the customer solve his problem from the first interaction without the need for the customer to call again. Further, employees operate as a team that shares the work responsibility; an employee can seek support from a more skilled colleague to solve a customer problem while on phone. Obviously, 
Table 1. Mean and Standard Deviation for Affective Commitment Questionnaire

\begin{tabular}{|c|c|c|c|c|c|}
\hline Item & No. & Min. & Max. & Mean & $\begin{array}{l}\text { Std. } \\
\text { deviation }\end{array}$ \\
\hline $\begin{array}{l}\text { Q1: I am willing to put great deal of effort beyond } \\
\text { that normally expected to this company be } \\
\text { successful. }\end{array}$ & 18 & 3.00 & 5.00 & 4.0588 & .8726 \\
\hline $\begin{array}{l}\text { Q2: I talk up this company to my friends as a great } \\
\text { organization to work for. }\end{array}$ & 18 & 2.00 & 5.00 & 3.8125 & 1.0740 \\
\hline $\begin{array}{l}\text { Q3: I would accept almost any type of job } \\
\text { assignment in order to keep working for this } \\
\text { company. }\end{array}$ & 18 & 1.00 & 4.00 & 2.9375 & 1.0289 \\
\hline $\begin{array}{l}\text { Q4: I find that my values and this company's } \\
\text { Values are very similar. }\end{array}$ & 18 & 2.00 & 5.00 & 3.8125 & 1.0178 \\
\hline $\begin{array}{l}\text { Q5: I am proud to tell others that I am part of this } \\
\text { company. }\end{array}$ & 18 & 2.00 & 5.00 & 3.8750 & 1.1143 \\
\hline $\begin{array}{l}\text { Q6: This company really inspires the best in me in } \\
\text { the way of job Performance. }\end{array}$ & 18 & 1.00 & 4.00 & 3.6250 & 1.0416 \\
\hline $\begin{array}{l}\text { Q7: I am extremely glad I chose this company to } \\
\text { work for over others I was considering at the time } \\
\text { I joined. }\end{array}$ & 18 & 2.00 & 5.00 & 4.0000 & 1.0226 \\
\hline Q8: I really care about the fate of this company. & 18 & 3.00 & 5.00 & 4.2500 & 0.7859 \\
\hline $\begin{array}{l}\text { Q9: For me, this is the best of all companies for } \\
\text { which to work }\end{array}$ & 18 & 2.00 & 5.00 & 3.5625 & 1.0431 \\
\hline $\begin{array}{l}\text { Overall mean } \\
\text { Internal Reliability (coefficient } \alpha \text { ) }\end{array}$ & & & & $\begin{array}{l}3.77 \\
0.94\end{array}$ & \\
\hline
\end{tabular}

employees working in this environment have a feeling of belonging and ownership of the workplace, they have the freedom to make decisions to provide a high quality service at relatively shorter time, and they enjoy the open channels of communication between themselves as well as other departments. When linking these job characteristics and environment offerings for employees with the antecedents of affective commitment discussed earlier, an expectation of high affective commitment level among employees can be concluded. The 9-item OCQ provided a value of 3.77 for the affective commitment level among employees that indeed proved the value-added to front-line employees life in the help desk in terms of work experience and personal achievements. The results achieved 


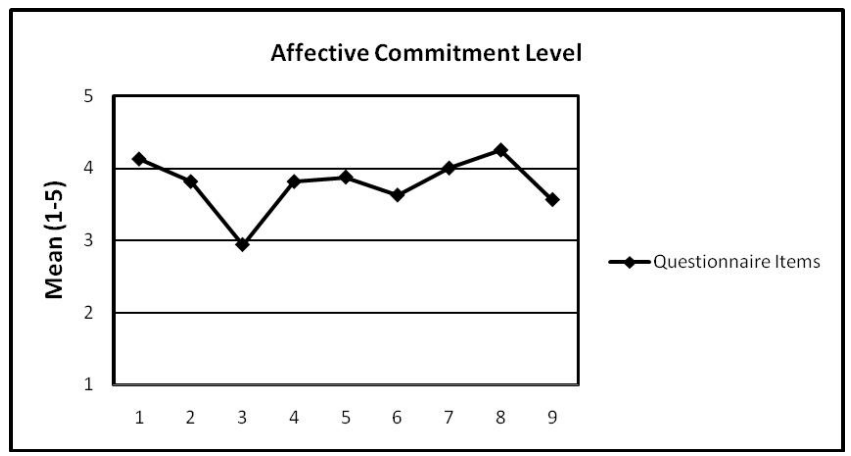

Fig. 1. Affective commitment of help desk staff

from interviews have indicated that lean manufacturing principles has provided clarity on the system due to the continuous demand analysis performed, this helped managers to identify potential problems in the services offered and thus the immediate corrective measures to be taken. Lean manufacturing principles were found to eliminate the waste in operations that helped managers to achieve automatic productivity and capacity improvements. Customers do not need to call again which allowed employees to handle more demands in an efficient way without cut in service, and eventually reduce resources consumption and overall costs. Further, the creation of a committed front-line employees in the help desk has significantly resulted in reducing the burden of managing people behaviour in the help desk as the general moral system of the workplace controls the human resources behaviour and not the traditional top-down hierarchy. Apparently, the affective commitment of employees accompanied with system waste elimination created a difference for the customer experience and added-value to the service encounter, no unproductive processes are used anymore and employees are willing to exert more effort on behalf of their organization to deliver excellent service.

Employees can provide a fast service even though the customers may be misunderstood and their information incorrectly entered [38]. Thus, business resources can be lost due to poor service delivery. Interviews with managers have identified that lean manufacturing principles have provided workplace with a relaxed environment without the need to stick to a pre-specified time allowance, this inevitably helped improve solution delivery processes, prevented calls repetition, and eventually allowed for resources savings. Another significant dimension of interest is the departmental integration. Open channels of communication between the ICT help desk and other departments affected by its work were established. Formal and informal communication at managers level allowed for significant information sharing. Further, lean manufacturing principles made it possible for management to identify the opportunities for making cost savings and performance improvements in the short and medium term, both from a corporate and service perspective. The waste elimination element of the system was 
viewed as a resources saving activity that used to be a major cause for capacity reduction. In addition, lean manufacturing allowed the ICT help desk to do more with less, fewer people are required to do more job, an opportunity has aroused to remove some agency workers and save money.

\section{Conclusion}

The fundamental objective of this research has been to investigate the impact of lean manufacturing principles utilization in public sector service departments for potential added value to employees' workplace. In this context, lean manufacturing principles is based on designing service operation systems around customer demand instead of in functional hierarchies. Managers in public services are realizing the need to employ more innovative interventions to achieve financial savings and better performance. As a result a shift has been noticed recently in management thinking in public services to adopt systems engineering models utilized in manufacturing sector. This has occurred due to the economical and governmental pressures exerted on councils and public services to generate substantial cost reductions and efficiency savings.

The evidence from this research indicates that the utilization of lean manufacturing systems in the public service departments has a strong relationship with the level of affective commitment among front-line employees. It is concluded that the ability of front-line employees to control the work and be involved in

decision making processes is a key factor for adding value to service departments and their employees.

\section{References}

1. McElhinney, D.: Concept of Entrapment and Decision-Making. Management Decision. 43(2), 189-202 (2005)

2. Jaaron, A., Backhouse, C.: Affective Commitment Stimulation Through Systems Thinking. QUIS 11: Moving Forward with Service Quality International conference, pp. 291-299. Ingolstadt School of Management, Catholic University EichstaettIngolstadt, Wolfsburg, Germany (2009)

3. Dean, A.M.: Service Quality in Call Centres: Implications for Customer Loyalty. Managing Service Quality. 12(6), 414-423 (2002)

4. Bain, P., Watson, A., Mulvey, G., Taylor, P. and Gall, G.: Taylorism, Targets and the Pursuit of Quantity and Quality by Call Centre Management. New Technology, Work and Employment. 17(3), 170-185 (2002)

5. Mahesh, V.S.: Improving Call Centre Agent Performance: A UK-India Study Based on the Agent Point of View. International Journal of Service Industry Management. $17(2), 136-157$ (2006)

6. Jaaron, A., Backhouse, C.: Systems Thinking for Call Centre Service design: Affective Commitment Implications in Manufacturing Enterprises. Working Paper, European Association for Research on Services (RESER) Publications (2009) 
7. Robertson, M.: Application of Lean Production and Agile Manufacturing Concepts in A Telecommunications Environment. International Journal of Agile Management Systems. 1(1), 14-17 (1999)

8. Levitt, T.: The Industrialisation of Service. Harvard Business Review. 54(5), 32-43 (1976)

9. Bowen, D.E., Youngdahl, W.E.: "Lean" Service: in Defense of a Production-Line Approach. International Journal of Service Industry Management. 9(3), 207-225 (1998)

10. Ohno, T.: Toyota Production System: Beyond Large-Scale Production. Porductivity Press, New York (1988)

11. Christopher, M.: Supply Chain Migration from Lean and Functional to Agile and Customised. Supply Chain Management: An International Journal. 5(4), 206-213 (2000)

12. Busi, M.: Seeing the Value in Customer Service. White Paper, The centre for Business Process Outsourcing, University of Strathclyde, Glasgow, UK (2005)

13. Sugimori, Y., Kusunoki, K., Cho, F., Uchikawa, S.: Toyota Production System and Kanban System Materialization of Just-In-Time and Respect-For-Human System. International Journal of Production Research. 15(6), 553-564 (1977)

14. Wan, H., Chen, F.F.: A Leanness Measure of Manufacturing Systems for Quantifying Impacts of Lean Initiatives. International Journal of Production Research. 46(23), 6567-6584 (2008)

15. Forrester, R.: Implications of Lean Manufacturing for Human Resource Strategy. Work Study. 44(3), 20-24 (1995)

16. Seddon, J.: Freedom from Command and Control: A Better Way to Make the Work Work. Vanguard Education, Buckingham, England (2003)

17. Robey, D., Sales, C.A.: Designing Organization. Fourth Edition, McGrawHill/Irwin, USA (1994)

18. Seddon, J.: Freedom from Command and Control. Management Services. Enfield, vol. 49(2), 22-24 (2005)

19. Commeiras, N., Fournier, C.: Critical Evaluation of Porter et al.s Organizational Commitment Questionnaire: Implications for Researchers. The Journal of Personal Selling and Sales Management. 21(3), 239-245 (2001)

20. Mathieu, J.E., Zajac, D.M.: A Review and Meta-Analysis of the Antecedents, Correlates, and Consequences of Organizational Commitment. Psychological Bulletin; Washington. 108(2), 171-194 (1990)

21. Mowday, R.T., Steers, R.M., Porter, L.W.: The Measurement of Organizational Commitment. Journal of Vocational Behavior. 14(2), 224-247 (1979)

22. Meyer, J.P., Allen, N.J.: A Three-Component Conceptualization of Organizational Commitment. Human Resources Management Review.1(1), 61-89 (1991)

23. Allen, N.J., Meyer, J.P.: The Measurement and Antecedents of Affective, Continuance and Normative Commitment to the Organization. Journal of Occupational Psychology; Leicester. 63(1), 1-18 (1990)

24. De Ruyter, K.: Commitment in AuditorClient Relationships: Antecedents and Consequences. Accounting, Organizations and Society. 24(1), 57-75 (1999)

25. Malhotra, N., Mukherjee, A.: The Relative Influence of Organizational Commitment and Job Satisfaction on Service Quality of Customer-Contact Employees in Banking Call Centres. Journal of Services Marketing. 18(3), 162-174 (2004)

26. Mowday, R.T., Porter, L.W., Steers, R.M.: Employee-Organization Linkages: The Psychology of Commitment, Absenteeism, and Turnover. Academic press, New York (1982) 
27. Van Emmrik, I.J. Hetty, Sanders, K.: Mismatch in Working Hours and Affective Commitment: Differential Relationships for Distinct Employee Groups. Journal of Managerial Psychology. 20(8), 712-726 (2005)

28. Mayer, J.P., Allen, N.J., Smith, C.A.: Commitment to Organizations and Occupations: Extension and Test of A Three- Component Conceptualization. Journal of Applied Psychology. 78(4), 538-551 (1993)

29. Taylor, P., Mulvey, G., Hyman, J., Bain, P.: Work Organization, Control and the Experience of Work in Call Centres. Work, Employment and Society. 16(1), 133-150 (2002)

30. Ellis, V.,Taylor, P.: 'You Don't Know What You've Got Till it's Gone': ReContextualising the Origins, Development and Impact of the Call Centre. New Technology, Work and Employment. 21(2), 107-122 (2006)

31. Varca, P.: Telephone Surveillance in Call Centres: Prescriptions for Reducing Strain. Managing Service Quality. 16(3), 290-305 (2006)

32. Krenzelok, E.P., Dean, B.S.: The Cost of Employee Turnover to a Regional Poison Information Centre. Veterinary and Human Toxicology. 36(1), 60-61 (1994)

33. Reichheld, F.F., Sasser, W.E.: Zero Defection: Quality Comes to Services. Harvard Business Review. 68(5), 105-111 (1990)

34. Taylor, S.J., Bogdan, R.: Introduction to Qualitative Research Methods: The Search for Meanings. John Wiley and Sons, New York (1984)

35. Attride-Stirling, J.: Thematic Networks: An Analytic Tool for Qualitative Research. Qualitative Research. 1(3), 385-405 (2001)

36. Porter, L.W., Steers, R.M., Boulian, P.V.: Organizational Commitment, JobSatisfaction, and Turnover Among Psychiatric Technicians. Journal of Applied Psychology; Washington. 59(5), 603-609 (1974)

37. Armistead, C., kiely, J., hole, L., Prescott, J.: An Exploration of Managerial Issues in Call Centres. Managing Service Quality. 12(4), 246-256 (2002)

38. Cleveland, B.: Call Center Management On Fast Forward: Succeeding in Today's Dynamic Customer Contact Environment. First Edition, ICMI Press, Annapolis, Maryland, USA (2006) 